Jurnal Akuntansi dan Investasi, Vol. 18 No. 2, Hlm: 198-208 Juli 2017

Artikel ini tersedia di website: http:/journal.umy.ac.id/index.php/ai/article/view/2899

DOI: $10.18196 /$ jai.180283

\title{
Pengaruh Moralitas Individu dan Pengendalian Internal terhadap Kecurangan: Sebuah Studi Eksperimental
}

\author{
M. Harry Krishna Mulia'; Rahmat Febrianto'; Rayna Kartika² \\ 'Dinas Pendidikan Kota Padang, Jl. Bagindo Aziz Chan No.8, Sumatera Barat 25586, Indonesia
}

${ }^{2}$ Prodi Akuntansi Universitas Andalas, Limau Manis, Kota Padang, 25163, Indonesia

\begin{tabular}{l}
\hline A R T I C L E I N F O \\
\hline Article history: \\
received 25 Feb 2017 \\
revised 16 Jun 2017 \\
accepted 26 Jun 2017
\end{tabular}

Keywords:

Accounting Fraud;

Morality; Internal

Control; Experiment;

Behavior

\begin{abstract}
A B S T RACT
The purpose of this research was to examine the influence of individual morality and internal control on accounting fraud at students majoring in accounting. The research method in this study is an experimental method using a full factorial experimental design 2x2, involving 60 undergraduate students majoring in accounting Andalas University. The instruments used were mach IV test for individual morality and add to 10 matrices for internal control. Data were processed using SPSS version 21, using two-way ANOVA. The results showed that there was an interaction between individual morality and internal control. Conditions when there is an element of internal control affects people with high moral level to tend to not perform accounting fraud. While individuals with low moral level, there is or there is no internal control individuals tend to do the accounting fraud.
\end{abstract}

(C) 2017 JAI. All rights reserved

\section{PENDAHULUAN}

Saat ini, perkembangan dunia akuntansi sudah sangat pesat. Namun setiap keadaan selalu mempunyai dua sisi. Kemajuan akuntansi selain membawa manfaat bagi masyarakat juga bisa menjadi sumber masalah kecurangan (fraud) yang sangat kompleks, seperti timbulnya korupsi, manipulasi laporan keuangan, atau penyalahgunaan aset. Di Indonesia saja banyak terjadi kasus kecurangan dalam akuntansi. Kasus kejahatan perbankan atau manipulasi pajak. Strategik Indonesia menyatakan bahwa pada kuartal pertama 2011 saja, telah terjadi sembilan kasus pembobolan bank yang modus kejahatannya bukan hanya fraud tetapi juga lemahnya kontrol internal terhadap sumber daya manusia (Dwiantika, 2011).

Transparency International (TI) telah merilis data indeks persepsi korupsi (corruption perception index) untuk tahun 2015. Skor Indonesia adalah 36, pada urutan 88 dari 168 negara yang diamati. Rentang indeks CPI adalah 0-100 (0 dipersepsikan sangat korup, 100 sangat bersih). Skor 36 tersebut menunjukkan dapat diartikan bahwa korupsi di Indonesia masih tinggi.

Sektor pemerintahan juga tidak luput dari kecurangan akuntansi. Badan Pemeriksa Keuangan (BPK) melakukan pemeriksaan terhadap laporan keuangan pemerintah pusat dan laporan keuangan pemerintah daerah. Hasilnya, tercatat pada semester II tahun 2015 potensi kerugian negara adalah Rp.11,49 triliun. Dari potensi kerugian tersebut, $75 \%$ merupakan masalah pengendalian internal dan ketidakpatuhan terhadap peraturan perundang-undangan (Ikhtisar hasil pemeriksaan semester II tahun 2015, BPK, 2015).

Mazar et al. (2008) mendapatkan bukti bahwa religiusitas dapat mencegah kecurangan. Penelitian yang mereka lakukan memberikan bukti bahwa ketika subjek diminta untuk mengingat ajaran agama (Sepuluh Perintah Tuhan) tingkat kecurangan mereka lebih rendah dibandingkan dengan kelompok yang tidak diminta untuk mengingat ajaran agama. Padahal, di dalam riset tersebut, mereka tidak memastikan kesamaan agama subjek dan juga tidak memastikan apakah subjek memiliki agama atau tidak. Selain itu, mereka juga tidak menekankan pada nasehat tertentu dari ajaran agama tersebut. Artinya, ada kemungkinan masalah manipulasi eksperimental dan internalisasi subjek di dalam eksperimen mereka.

Studi ini menggunakan subjek dengan agama yang sama, namun dengan level moralitas yang berbeda. Mazar et al. (2008) tidak menggunakan karakteristik subjek yang demikian, malahan subjek tanpa agama sekalipun diizinkan ikut. Jadi perbedaan riset ini dengan studi Mazar et al. 
(2008) adalah pada karakteristik subjek, yaitu yang beragama sama. Kedua, riset ini menguji pengaruh perbedaan level moralitas terhadap kecurangan subjek. Mazar et al. (2008) tidak melakukan pembedaan tersebut.

Studi ini sejalan dengan Ramamoorti (2008) yang menyatakan bahwa faktor perilaku merupakan akar dari kecurangan. Level moralitas indivi$\mathrm{du}$, baik moralitas tinggi dan moralitas rendah dan elemen pengendalian internal organisasi, dan pengendalian internal merupakan faktor yang menarik untuk diteliti sebagai penyebab terjadinya kecurangan akuntansi. Menurut Graham (1995) dan Patterson (2001) seperti yang dikutip Moroney dan McDevitt (2008), individu yang bermoralitas tinggi tindakannya akan diatur oleh prinsip moralitas universal. Hal ini berarti individu yang bermoralitas tinggi tidak akan melakukan kecurangan.

Abiola dan Oyewole (2013) meneliti hubungan sistem pengendalian internal terhadap pendeteksian kecurangan pada bank di Nigeria. Penelitian ini menggunakan 10 bank dari 15 bank yang ada di daerah Lagos. Data yang dikumpulkan adalah data primer dan sekunder dan dianalisis menggunakan General Least Square Regression Analysis. Hasil penelitian menyimpulkan bahwa terdapat hubungan yang kuat dan signifikan antara sistem pengendalian internal dengan pendeteksian kecurangan. Penelitian Hernandez dan Groot (2007) menemukan bahwa etika dan lingkungan pengendalian akuntansi merupakan variabel penting dihubungkan dengan kecenderungan individu dalam melakukan kecurangan.

Sebaliknya, penelitian ini berbeda dengan Dewi (2014) yang menguji pengaruh moralitas individu dan pengendalian internal terhadap kecenderungan kecurangan akuntansi dengan desain penelitian eksperimen pada konteks pemerintahan daerah provinsi Bali. Pada penelitiannya, Dewi (2014) menggunakan instrumen berbasis kuisioner. Kuisioner tersebut diisi oleh pegawai pemerintah daerah provinsi Bali. Kelemahan dari penggunaan kuisioner kemunculan bias keelokan sosial (social desirability bias) sehingga tidak memperlihatkan perilaku yang sesungguhnya. Studi ini berbeda dengan penelitian Dewi (2014) karena desain eksperimen lebih menjamin keteramatan perilaku dibandingkan dengan desain non-eksperimental.

Hasil penelitian ini diharapkan dapat memberikan sumbangan referensi baru dalam menjelaskan perilaku kecurangan kuntansi dengan determinan moralitas dan pengendalian internal indi- vidu pada konteks agama yang sama. Selain itu, hasil penelitian ini dapat dijadikan bahan masukan dalam perumusan kebijakan oleh perumus peraturan (regulator) terkait individu yang menempati posisi penyusun laporan keuangan di suatu entitas.

\section{TINJAUAN LITERATUR DAN PERUMUSAN HIPOTESIS}

\section{Kecurangan Akuntansi}

Singleton dan Singleton (2010) mendefinisikan kecurangan pertama sebagai suatu kejahatan, dimana kecurangan merupakan istilah umum yang mencakup berbagai kelihaian manusia dimana satu individu mengambil keuntungan dari yang lain melalui gambaran yang salah. Kemudian, kecurangan sebagai suatu kesalahan, dimana kecurangan adalah tindakan yang disengaja dalam memberikan laporan tentang fakta-fakta material yang salah, sehingga seseorang salah dalam mengambil keputusan karena menganggap faktafakta itu benar. Terdapat dua jenis kejahatan, yakni:

(1) Kecurangan sebagai suatu kejahatan. Kecurangan merupakan istilah umum yang mencakup berbagai kelihaian manusia dimana satu individu mengambil keuntungan dari yang lain melalui gambaran yang salah.

(2) Kecurangan sebagai suatu kesalahan. Kecurangan adalah tindakan yang disengaja dalam memberikan laporan tentang faktafakta material yang salah, sehingga seseorang salah dalam mengambil keputusan karena menganggap fakta-fakta itu benar.

Sawyer et al. (2006) menyebutkan kecurangan adalah serangkaian tindakan-tindakan tidak wajar dan ilegal yang sengaja dilakukan untuk menipu, kecurangan dilakukan oleh individu atau organisasi untuk mendapatkan uang. Association of Certified Fraud Examiners (ACFE) mengelompokkan kecurangan dalam tiga kelompok. Kelompok pertama yaitu kecurangan laporan keuangan (financial statement fraud), yaitu tindakan yang dilakukan oleh pejabat atau eksekutif suatu perusahaan atau instansi pemerintah untuk menutupi kondisi keuangan yang sebenarnya dengan melakukan rekayasa keuangan dalam penyajian laporan keuangannya untuk memperoleh keun-tungan.

Kelompok kedua adalah penyalahgunaan aset (asset misappropriation), yaitu penyalahgu- 
naan/pencurian aset atau harta perusahaan atau pihak lain. Ini merupakan bentuk kecurangan yang paling mudah dideteksi karena sifatnya yang dapat diukur/dihitung (defined value). Sedangkan kelompok ketiga adalah korupsi, yaitu jenis kecurangan ini yang paling sulit dideteksi karena menyangkut kerja sama dengan pihak lain. Kecurangan jenis ini yang terbanyak terjadi di negaranegara berkembang yang penegakan hokumnya lemah dan masih kurang kesadaran akan tata kelola yang baik sehingga faktor integritasnya masih dipertanyakan. Bentuk-bentuk korupsi bisa berupa penyalahgunaan wewenang/konflik kepentingan (conflict of interest), penyuapan (bribery), penerimaan yang tidak sah/ilegal (illegal gratuities), dan pemerasan secara ekonomi (economic extortion). Secara rinci, dapat dibagi menjadi;

(1) Kecurangan laporan keuangan (financial statement fraud), yaitu tindakan yang dilakukan oleh pejabat atau eksekutif suatu perusahaan atau instansi pemerintah untuk menutupi kondisi keuangan yang sebenarnya dengan melakukan rekayasa keuangan dalam penyajian laporan keuangannya untuk memperoleh keuntungan.

(2) Penyalahgunaan aset (asset misappropriation), yaitu penyalahgunaan/pencurian aset atau harta perusahaan atau pihak lain. Ini merupakan bentuk kecurangan yang paling mudah dideteksi karena sifatnya yang dapat diukur/dihitung (defined value).

(3) Korupsi, yaitu jenis kecurangan ini yang paling sulit dideteksi karena menyangkut kerja sama dengan pihak lain. Kecurangan jenis ini yang terbanyak terjadi di negaranegara berkembang yang penegakan hukumnya lemah dan masih kurang kesadaran akan tata kelola yang baik sehingga faktor integritasnya masih dipertanyakan. Bentukbentuk korupsi bisa berupa penyalahgunaan wewenang/konflik kepentingan (conflict of interest), penyuapan (bribery), penerimaan yang tidak sah/ilegal (ilegal gratuities), dan pemerasan secara ekonomi (economic extortion).

\section{Moralitas}

Model Kohlberg merupakan salah satu teori perkembangan moral yang banyak digunakan dalam penelitian etika. Kohlberg (1969) menyatakan bahwa ada tiga tahapan dalam perkembangan moral, yaitu tahapan pra-konvensional, taha- pan konvensional dan tahapan pasca-konvensional.

Liyanarachi (2009) memaparkan bahwa level penalaran moral individu akan mempengaruhi perilaku etis mereka. Orang yang mempunyai level penalaran moral yang rendah berperilaku berbeda dengan orang yang memiliki level penalaran moral yang tinggi di saat mereka menghadapi dilema etika. Semakin tinggi level penalaran moral seseorang, maka individu tersebut semakin mungkin untuk melakukan 'hal yang benar'. Individu akan melakukan suatu tindakan karena takut terhadap hukum/peraturan yang ada jika berada pada tahapan yang paling rendah (prakonvensional). Selain itu individu pada level moral ini juga akan memandang kepentingan pribadinya sebagai hal yang utama dalam melakukan suatu tindakan.

Pada tahap kedua (konvensional), individu akan mendasarkan tindakannya pada persetujuan teman-teman dan keluarganya dan juga pada norma-norma yang ada di masyarakat. Pada tahap tertinggi (pasca-konvensional), individu mendasari tindakannya dengan memperhatikan kepentingan orang lain dan berdasarkan tindakannya pada hukum-hukum universal. Menurut Rest (2000), semakin tinggi level moral seseorang maka semakin besar kemungkinan mereka melakukan 'hal yang benar'.

\section{Pengendalian Internal}

Menurut Peraturan Pemerintah Republik Indonesia nomor 60 tahun 2008 tentang sistem pengendalian internal pemerintah, sistem pengendalian internal merupakan proses yang integral pada tindakan dan kegiatan yang dilakukan secara terus menerus oleh pimpinan dan seluruh pegawai untuk memberikan keyakinan memadai atas tercapainya tujuan organisasi melalui kegiatan yang efektif dan efisien, keandalan pelaporan keuangan, pengamanan aset negara, dan ketaatan terhadap peraturan perundang-undangan.

Konsep pengendalian yang direkomendasikan oleh COSO (2013) adalah konsep pengendalian internal sebagai suatu kerangka terpadu (integrated framework). COSO (2013) mengenalkan bahwa terdapat lima komponen kebijakan dan prosedur yang perlu didesain dan dimplementasikan untuk memberikan jaminan bahwa tujuan pengendalian akan dapat dicapai, yakni:

(1) Control environment (lingkungan pengendalian) yang menciptakan suasana pengen- 
dalian dalam suatu organisasi dan kesadaran personil organisasi tentang pengendalian.

(2) Management risk assessment (penilaian risiko manajemen) yaitu identifikasi, analisis pengelolaan resiko yang berkaitan dengan penyusunan laporan keuangan, sesuai dengan sesuai dengan prinsip akuntansi berlaku umum

(3) Accounting information and communication system (sistem komunikasi dan informasi akuntansi) yaitu sistem akuntansi yang diciptakan untuk mengidentifikasi, merakit, menggolongkan, menganalisis, mencatat dan melaporkan transaksi suatu entitas, serta menyelenggarakan pertanggungjawaban kekayaan dan utang entitas tersebut

(4) Control activities (aktivitas pengendalian) yaitu kebijakan dan posedur yang dibuat untuk memberikan keyakinan bahwa petunjuk yang dibuat oleh manajemen dilaksanakan

(5) Monitoring (pemantauan) yaitu proses penilaian mutu kinerja sestem pengendalian intern sepanjang waktu.

Coram et al. (2008) menjelaskan bahwa organisasi yang memiliki fungsi audit internal akan lebih dapat mendeteksi kecurangan akuntansi. Sistem pengendalian internal menyediakan mekanisme untuk mendeteksi keterjadian suatu kecurangan, baik ketika kecurangan itu terjadi, maupun sebelum terjadi. Bastian (2015) menyebutkan bahwa pengendalian akuntansi merupakan bagian dari sistem pengendalian internal, meliputi struktur organisasi, metode, dan ukuran-ukuran yang dikoordinasikan terutama untuk menjaga kekayaan organisasi serta mengecek ketelitian dan keandalan data akuntansi. Artinya, informasi akuntansi, sebagai produk dari sistem akuntansi, bisa menjadi alat untuk mendeteksi kecurangan.

Menurut Sawyer et al. (2005) pengendalian internal adalah setiap tindakan yang diambil manajemen untuk meningkatkan kemungkinan tercapainya tujuan dan sasaran yang ditetapkan. Pengendalian internal bersifat preventif (untuk mencegah terjadinya hal-hal yang tidak diinginkan), detektif (untuk mendeteksi dan memperbaiki hal-hal yang tidak diinginkan yang telah terjadi), dan direktif (untuk menyebabkan atau mengarahkan terjadinya hal-hal yang diinginkan).

Sementara itu, Arens et al. (2004) mendefinisikan pengendalian internal sebagai proses yang dirancang untuk menyediakan jaminan yang layak mengenai pencapaian dari sasaran manajemen dalam kategori sebagai berikut; (1) keandalan laporan keuangan, (2) efektifitas dan efisiensi dari operasional dan (3) pemenuhan dengan ketentuan hukum dan peraturan yang biasa diterapkan.

\section{Pengembangan hipotesis penelitian}

Dalam penelitian ini variabel yang akan diteliti adalah moralitas individu dan pengendalian internal. Coram et al. (2008) menjelaskan bahwa sebuah organisasi yang mempunyai fungsi audit internal akan dapat mendeteksi kecurangan akuntansi. Penelitian Moroney dan McDevitt (2008) menyatakan individu dengan level penalaran moral tinggi dalam perbuatannya akan lebih mengedepankan prinsip-prinsip moral yang universal.

Sementara itu menurut Puspasari (2012) ada interaksi antara moralitas individu dan pengendalian internal dalam mempengaruhi kecenderungan kecurangan akuntansi. Interaksi yang dimaksud merupakan perubahan pada satu level faktor moral atau pada kondisi pengendalian internal akan menyebabkan perubahan individu dalam melakukan kecurangan akuntansi. Individu dengan moralitas rendah cenderung untuk memanfaatkan kondisi yang tidak terdapat elemen pengendalian internal dalam suatu organisasi untuk kepentingan pribadinya (self-interest), seperti tindakan yang berhubungan dengan kecurangan akuntansi. Kondisi tersebut sesuai dengan tingkatan level pre-conventional Kohlberg. Individu dengan moralitas tinggi dalam kondisi tidak terdapat elemen pengendalian internal di organisasi tetap tidak akan melakukan kecurangan akuntansi yang tidak etis dan akan merugikan banyak pihak.

Pada level moral pre-conventional, Kohlberg menyatakan bahwa individu yang hanya taat kepada peraturan yang ada karena menghindari sanksi tertentu termasuk dalam tahap yang rendah. Individu dengan moralitas rendah cenderung tidak akan melakukan kecurangan akuntansi dalam kondisi terdapat elemen pengendalian internal karena takut perbuatannya akan terdeteksi oleh pengendalian internal organisasi karena dia takut mendapat sanksi hukum. Hal ini sesuai dengan temuan dari Moroney dan McDevitt (2008) yang menemukan bahwa individu dengan level penalaran moral rendah lebih berorientasi pada peraturan dan sanksi hukum yang mungkin didapatkan.

Penelitian Mazar et al. (2008) tentang kecurangan individu menyatakan bahwa setelah 
mereka melakukan beberapa percobaan, mereka menyimpulkan ketika seseorang punya kesempatan untuk berbuat curang, mereka akan melakukannya, tetapi tingkat ketidakjujuran per orang relatif rendah. Ariely (2009) Ini sejalan dengan Ariely (2009) menyatakan bahwa ketika partisipan dihadapkan dengan kondisi di mana bisa melakukan kecurangan, partisipan melakukannya pada batas di mana si partisipan merasa nyaman melakukan kecurangan. Contohnya adalah ketika seseorang membawa pulang pensil dari kantor. Banyak pembenaran yang bisa digunakan. Misalnya, "semua orang melakukannya", atau "saya bawa pulang karena saya bisa kerjakan pekerjaan di rumah”. Ariely mencontohkan ketika partisipan dalam grup ujinya diperintahkan merobek lembar kertas kerja add to 10 matrices yang dikerjakan, sebelum melaporkan berapa jumlah yang mereka benar kerjakan, banyak dari mereka yang curang dan jumlah yang mereka curangi tersebut tidak berubah ketika mereka ditawari duit yang lebih banyak atas jumlah benar yang mereka kerjakan. Kebijakan konvensional mengasumsikan orang berbuat kecurangan berdasarkan apakah mereka pikir mereka akan tertangkap dan tingkat hukuman yang akan mereka terima.

Beberapa riset menunjukkan bahwa moralitas bisa mempengaruhi perilaku orang. Moralitas seseorang bisa mempengaruhinya untuk melakukan atau tidak melakukan kecurangan. Untuk berani melakukan sebuah kecurangan, seseorang harus mencari cara untuk merasionalisasi tindakannya tersebut. Seseorang berani melakukan kecurangan, jika menurut rasionalisasinya tindakan curangnya tidak akan melukai harga dirinya.

Penelitian yang dilakukan oleh Ayal dan Gino (2011) dan Gino et al. (2009) menyimpulkan bahwa ketika orang memiliki kesempatan untuk curang saat probabilitas untuk tertangkap dan biaya reputasional bisa diminimumkan, maka sebagian besar orang akan berlaku curang. Namun, perbuatan mereka tersebut hanya sekedar untuk mendapatkan keuntungan finansial, tidak sedemikian rupa bisa menciptakan citra negatif bagi diri mereka (Mazar dan dan Ariely, 2006).

Ketika seseorang mengalami dilema etis seringkali akan muncul konflik antara apakah akan berperilaku etis sehingga tetap bisa mempertahankan citra positif diri, atau berperilaku tidak etis agar tetap bisa mendahulukan kepentingan pribadi (Gino et al., 2011, Mead et al., 2009). Ketika berhadapan dengan dilema etis seperti itu, orang seringkali memecahkan konflik dengan penilaian-ulang yang kreatif (creative reassessment) dan rasionalisasi mau-menang-sendiri (self-serving rationalization) (Gino dan Ariely, 2012, Shalvi et al., 2011). Dengan cara ini, orang bisa bertindak dengan tidak jujur demi keuntungan tak etis, namun masih cukup jujur untuk mempertahankan konsep diri yang positif mereka (Gino et al., 2009, Mazar et al., 2008).

Riset Mazar et al. (2008) mengindikasikan bahwa jika seseorang diingatkan pada suatu nilai moral yang seharusnya ia miliki, maka ia tidak akan melakukan kecurangan jika kesempatan untuk melakukan kecurangan itu ada karena pada saat itu ia berada pada level moral yang tinggi. Implisit di dalam simpulan mereka adalah bahwa seseorang yang berada pada level moralitas yang tinggi tidak akan berlaku curang. Hipotesis pertama yang bisa diturunkan dari logika ini adalah sebagai berikut:

$\mathrm{H}_{1}$ : Terdapat perbedaan kecenderungan kecurangan antara individu yang memiliki level moralitas tinggi dan level moralitas rendah.

Fungsi pengendalian internal perusahaan adalah untuk mencegah kehilangan aset perusahaan. Karena pencurian atau kecurangan harus selalu disertai dengan motif dan kesempatan, maka perusahaan tidak pernah tahu kapan asetnya akan dicuri atau kapan suatu kecurangan akan muncul. Tambahan lagi perusahaan tidak dapat mendeteksi level moralitas dari pegawainya. Oleh sebab itu, keberadaan sistem pengendalian internal dibutuhkan untuk mencegah terjadinya kecurangan ketika kesempatan, rasionalisasi dan motif tersedia.Fungsi pengendalian internal perusahaan adalah untuk mencegah kehilangan aset perusahaan. Karena pencurian atau kecurangan harus selalu disertai dengan motif dan kesempatan, maka perusahaan tidak pernah tahu kapan asetnya akan dicuri atau kapan suatu kecurangan akan muncul. Oleh sebab itu, keberadaan sistem pengendalian internal dibutuhkan untuk mencegah terjadinya kecurangan ketika kesempatan, rasionalisasi dan motif tersedia. Hipotesis kedua dirumuskan sebagai berikut:

$\mathrm{H}_{2}$ : Terdapat perbedaan kecenderungan kecurangan antara individu dalam kondisi terdapat elemen pengendalian internal dan tidak terdapat elemen pengendalian internal.

Jika seorang individu memiliki moral yang tinggi, maka mungkin tidak dibutuhkan sebuah fungsi pengendalian internal yang mencegahnya untuk melakukan kecurangan. Dimana seseorang tetap akan berhenti pada lampu merah walaupun 
tidak ada polisi yang mengawasi. Pengendalian internal lebih cenderung dibutuhkan pada kondisi individu memiliki moralitas yang rendah. Namun, logika ini tidak sejalan dengan pendapat sebagian orang tentang segitiga kecurangan (Cressey, 1973). Cressey menyiratkan bahwa kecurangan hanya disebabkan oleh kesempatan, rasionalisasi, dan motif. Moralitas tidak menjadi pendorong kecurangan, karena setiap pelaku kecurangan tidak pernah mencerap terlanggarnya prinsip moralitasnya. Namun, riset Mazar et al. (2008) mengindikasikan bahwa moralitas bisa mencegah kecurangan dan berinteraksi dengan pengendalian internal untuk mempengaruhi kecurangan individu. Jika seorang individu memiliki moral yang tinggi, maka mungkin tidak dibutuhkan sebuah fungsi pengendalian internal yang mencegahnya untuk melakukan kecurangan. Pengendalian internal lebih cenderung dibutuhkan pada kondisi individu memiliki moralitas yang rendah. Namun, logika ini tidak sejalan dengan pendapat sebagian orang tentang segitiga kecurangan (Cressey, 1973). Cressey menyiratkan bahwa kecurangan hanya disebabkan oleh kesempatan, rasionalisasi, dan motif. Moralitas tidak menjadi pendorong kecurangan, karena setiap pelaku kecurangan tidak pernah mencerap terlanggarnya prinsip moralitasnya. Namun, riset Mazar et al. (2008) mengindikasikan bahwa moralitas bisa mencegah kecurangan dan berinteraksi dengan pengendalian internal untuk mempengaruhi kecurangan individu. Hipotesis ketiga adalah sebagai berikut:

$\mathrm{H}_{3}$ : Pengaruh pengendalian internal terhadap kecurangan dipengaruhi oleh moralitas individu.

\section{METODE PENELITIAN}

\section{Jenis dan Desain Penelitian}

Penelitian yang kami lakukan ini adalah penelitian dengan metode eksperimen. Penelitian eksperimen yang kami lakukan menggunakan desain full factorial $2 \times 2$. Studi ini menguji pengaruh dua variabel independen, yaitu moralitas individu (tinggi dan rendah) dan pengendalian internal (ada dan tidak ada) terhadap satu variabel dependen, yaitu kecurangan.

\section{Partisipan}

Penelitian ini menggunakan partisipan dari mahasiswa S1 jurusan akuntansi Universitas
Andalas. Penggunaan mahasiswa sebagai di dalam eksperimen berdasarkan pendapat Remus (1986) yang menyatakan bahwa bahwa pembuatan keputusan oleh mahasiswa bisa paralel dengan pembuatan keputusan oleh manajer. Pendapat senada diberikan oleh Houghton dan Hronsky (1993) menyimpulkan bahwa tidak ditemukan perbedaan signifikan antara struktur faktor individual grup mahasiswa dengan grup praktisi. Studi Houghton dan Hronsky (1993) ini memberi bukti tentang kesesuaian mahasiswa sebagai surogat untuk praktisi akuntansi pada tugas-tugas yang melibatkan pengukuran sebuah makna. Mereka menyatakan bahwa mahasiswa yang tidak berpengalaman namun terdidik dan kolega praktisi akuntansi memiliki struktur kognitif yang serupa sehubungan dengan konsep akuntansi. Penggunaan mahasiswa ini karena peneliti ingin mengetahui apakah hasil penelitian yang dilakukan oleh Dewi (2014) juga akan sama bila partisipannya adalah yang berusia muda, masih dalam tahap belajar dan belum terpapar kerasnya dunia kerja. Subjek eksperimen didapat secara sukarela, melalui penjaringan ke dalam kelas-kelas.

\section{Penugasan dalam Eksperimen}

Eksperimen dilakukan selama dua minggu. Minggu pertama merupakan tes untuk menentukan tingkat moralitas partisipan. Partisipan akan terbagi menjadi dua kelompok, yang bermoralitas rendah dan bermoralitas tinggi. Setelah tes pada minggu pertama tersebut dilakukan dan partisipan terbagi menjadi dua kelompok, maka pada minggu kedua dilakukan tes untuk menguji kecurangan partisipan. Sehingga masing-masing kelompok akan diuji dengan kondisi terdapat pengendalian internal dan tidak terdapat pengendalian internal.

Pada minggu pertama eksperimen ini semua mahasiswa tersebut diberi Mach IV test. Tes ini adalah untuk membagi partisipan menjadi dua kelompok yaitu moralitas rendah dan moralitas tinggi. Rendah atau tingginya moralitas individu ini ditentukan dari skor yang mereka hasilkan. Bila skor yang dihasilkan lebih besar dari 60 maka dianggap individu tersebut bermoral rendah sedangkan bila skor nya di bawah 60, maka dianggap individu tersebut bermoral tinggi. Hal ini berdasarkan penjelasan Pope (2005) dan Kramer (2014).

Tes minggu kedua ini adalah add to 10 matrices yang diadopsi dan dikembangkan lagi dari Mazar et al. (2008). Partisipan diberi formulir berupa satu lembar kertas kerja, yang berisi dua 
puluh buah matriks $3 \times 4$. Mereka diminta mencari dua angka dari tiap matriks yang berjumlah sepuluh (Mazar et al., 2008). Contoh matriks ada di tabel di bawah ini.

Tabel 1. Contoh Matrik Penjumlahan Sepuluh

\begin{tabular}{lll}
1.69 & 1.82 & 2.91 \\
4.67 & 4.81 & 3.05 \\
5.82 & 5.06 & 4.28 \\
6.36 & 5.19 & 4.57 \\
\hline
\end{tabular}

Pada kelas yang perlakuannya ada pengendalian internal atau kondisinya dikendalikan, semua kertas kerja dari setiap partisipan dikembalikan ke peneliti. Lalu peneliti menghitung dan membayar partisipan sesuai dengan jumlah matriks yang benar dikerjakan. Sementara itu, pada kelas yang kondisinya tidak dikendalikan atau tidak ada pengendalian internal, partisipan membuang kertas kerjanya ke tempat sampah. Lalu partisipan menyampaikan/menyebutkan sendiri berapa matriks yang benar yang sudah diselesaikan, untuk kemudian dibayar oleh peneliti. Pembuangan kertas kerja ke tempat sampah memberi isyarat kepada subjek bahwa mereka bisa mengklaim jawaban benar yang lebih banyak daripada yang sebenarnya ia jawab.

Satu matriks yang benar dihargai sebesar Rp.2.000 sehingga bila partisipan mengatakan dia telah benar mengisi matriks sebanyak 20 buah, maka partisipan akan mendapat bayaran sebesar Rp.40.000 (empat puluh ribu rupiah). Untuk mendorong subjek menjawab setingggi yang ia anggap pantas, maka sebelum pelaksanaan tugas kedua ini, peneliti juga menjanjikan hadiah tersendiri bagi subjek dengan nilai klaim tertinggi.

\section{Instrumen Penelitian}

Instrumen yang digunakan pada penelitian eksperimen ini adalah Machiavellian test dan add

\footnotetext{
${ }^{1}$ Walaupun subjek membuang kertasnya ke kantong sampah yang disedikan oleh peneliti, kertas yang dibuang tidak dirobek oleh subjek. Tindakan pembuangan ini memberi kesan bahwa peneliti tidak akan bisa memverifikasi jumlah klaim dengan ketepatan sesungguhnya. Sebenarnya, di setiap kertas, peneliti menyelipkan angka pengenal tertentu yang mengarah kepada subjek yang menjawabnya. Dari pengecekan pasca-eksperimen peneliti bisa menentukan berapa sebenarnya ketepatan perhitungan subjek dan selisih dengan klaimnya sehingga diperoleh nilai kecurangannya.
}

to 10 matrices. Instrumen pertama adalah Mach IV test/Machiavellian test, digunakan untuk mengukur tingkat moralitas partisipan (rendah atau tinggi). Tes ini berisi dua puluh pertanyaan yang telah dibuat disusun sedemikian rupa oleh Christie dan Geis (1970). Di setiap pertanyaan partisipan harus memilih angka satu sampai lima tergantung mana yang cocok dengan pribadinya.

Instrumen berikutnya adalah add to 10 matrices yang digunakan untuk mengukur pengendalian internal. Instrumen ini telah digunakan oleh Ariely pada sekitar 35.000 orang, yang mana sekitar 20.000 orang diantaranya melakukan kecurangan (Ariely, 2013). Lembar kertas kerja ini terdiri dari 20 buah matriks $3 \times 4$. Partisipan diminta mencari dua angka dari tiap matriks yang jumlahnya 10 .

\section{HASIL DAN PEMBAHASAN}

\section{Karakteristik Partisipan}

Penelitian ini dilakukan pada mahasiswa S-1 jurusan Akuntansi Universitas Andalas. Jumlah partisipan awalnya berjumlah 108 orang, yaitu yang ikut dalam pengujian pertama mengisi kuisioner Mach IV test. Namun, tujuh orang di anggap gugur, karena tidak mengisi tes yang kedua, yaitu add to 10 matrices test sehingga partisipan tersisa sebanyak 101 orang. Dari 101 orang, ketika diuji, ternyata ada sekitar 10 orang yang datanya dianggap outlier. Ketika data yang 91 orang diuji lagi, ternyata data tidak terdistribusi dengan normal. Sekaran (2006) memberikan pedoman penentuan jumlah sampel yaitu untuk penelitian eksperimen yang sederhana, dengan pengendalian yang ketat, ukuran sampel bisa antara 10-20 elemen. Sehingga peneliti memutuskan untuk mengurangi sampel dan hanya menggunakan sampel sebanyak 60 orang saja, atau sebanyak 15 sampel tiap selnya. Berikut ini adalah hasil pengolahan data tentang pengelompokan partisipan secara keseluruhan yang ditunjukkan pada Tabel 2.

\section{Statistik Deskriptif}

Tabel 3 menunjukkan bahwa partisipan dalam grup 2, dengan perlakuan tidak terdapat elemen pengendalian internal dan level moral tinggi memiliki mean yang paling tinggi yaitu sebesar -2,33. Grup empat dengan perlakuan terdapat elemen pengendalian internal dan level 
moral tinggi memiliki mean paling rendah yaitu 0,93. Sementara grup satu dengan level moral rendah dan pada kondisi tidak ada pengendalian internal memiliki mean -2,07. Grup tiga dengan level moralitas rendah dan kondisi tidak ada pengendalian internal memilik mean -2,13. Bila dilihat dari mean per sel, berarti grup dua dengan mean paling tinggi memiliki tingkat kecurangan paling tinggi. Sementara grup empat yang mean paling rendah, berarti tingkat kecurangannya rendah. Berikut adalah Tabel 2 dan 3 yang menyajikan hasil statistik deskriptif keempat grup tersebut.

Tabel Tabel 2. Karakteristik Partisipan

\begin{tabular}{lccc}
\hline \multirow{2}{*}{ Kondisi } & \multicolumn{2}{c}{ Pengendalian Intern } \\
\cline { 3 - 4 } & & Tidak ada & Ada \\
\hline \multirow{2}{*}{ Moralitas } & Rendah & 15 & 15 \\
\cline { 2 - 4 } & Tinggi & 15 & 15 \\
\hline
\end{tabular}

Tabel 3. Statistik Deskriptif Deskriptif

\begin{tabular}{clll}
\hline \multirow{2}{*}{ Kondisi } & \multicolumn{2}{c}{ Pengendalian Intern } \\
\cline { 2 - 4 } & \multirow{3}{*}{ Rendah } & \multicolumn{1}{c}{ Tidak ada } & \multicolumn{1}{c}{ Ada } \\
\hline \multirow{4}{*}{ Moralitas: } & Mean: $-2,07$ & Mean: $-2,13$ \\
& & Dev.standar: & Dev.standar: \\
& \multirow{2}{*}{ Tinggi } & Mean: $-2,33$ & Mean: $-0,93$ \\
& & Dev..standar: & Dev.standar: \\
& & 1,397 & 1,100 \\
\hline
\end{tabular}

Efek utama (main effect) merupakan efek yang secara langsung ditimbulkan oleh variabel bebas atau independen tanpa memperhitungkan kehadiran variabel independen lain. Tabel 4 menunjukkan nilai mean tiap sel dan mean marginal estimasian. Perbedaan nilai rata-rata antara grup yang bermoralitas rendah dengan bermoralitas tinggi adalah $0,47(2,10$ - 1,63), dengan nilai signifikansi sebesar 0,196. Perbedaan mean ini secara statistik adalah tidak signifikan $(\mathrm{p}>0,05)$. Hasil ini mengindikasikan bahwa moralitas tidak berpengaruh kepada kecurangan individu. Hasil ini tidak sejalan dengan hasil penelitian Mazar et al. (2008). Penelitian tersebut menyiratkan bahwa moralitas memainkan peran dalam mencegah kecurangan.

Kedua, perbedaan nilai rata-rata antara grup yang tidak memiliki pengendalian internal dengan yang memilikinya adalah $0,67(2,20-1,53)$ dengan nilai signifikansi sebesar 0,067. Perbedaan mean ini secara statistik adalah signifikan pada alfa $10 \%$ $(\mathrm{p}<0,10)$. Hasil pengujian ini mengindikasikan bahwa pengendalian internal memiliki peran untuk mencegah kecurangan. Hasil pengujian ini menguatkan temuan Mazar et al. (2008) dan Gino et al. (2013), di antara beberapa riset yang lain.

\section{Tabel 4. Marginal Mean}

\begin{tabular}{lccccc}
\hline \multirow{2}{*}{ Kondisi } & \multicolumn{2}{c}{ Pengendalian } & \multicolumn{2}{c}{ Margi } \\
& & $\begin{array}{c}\text { Tntern } \\
\text { Tidak } \\
\text { ada }\end{array}$ & Ada & Mean & Sig. \\
& Rendah & $-2,07$ & $-2,13$ & $-2,10$ & 0,196 \\
Moralitas & Tinggi & $-2,33$ & $-0,93$ & $-1,63$ & \\
Marginal Mean & $-2,20$ & $-1,53$ & & \\
\begin{tabular}{l} 
Sig. \\
\hline
\end{tabular} & & & & $0,067^{*}$ \\
\hline
\end{tabular}

${ }^{\text {* }}$ Signifikan pada alpha 0,05

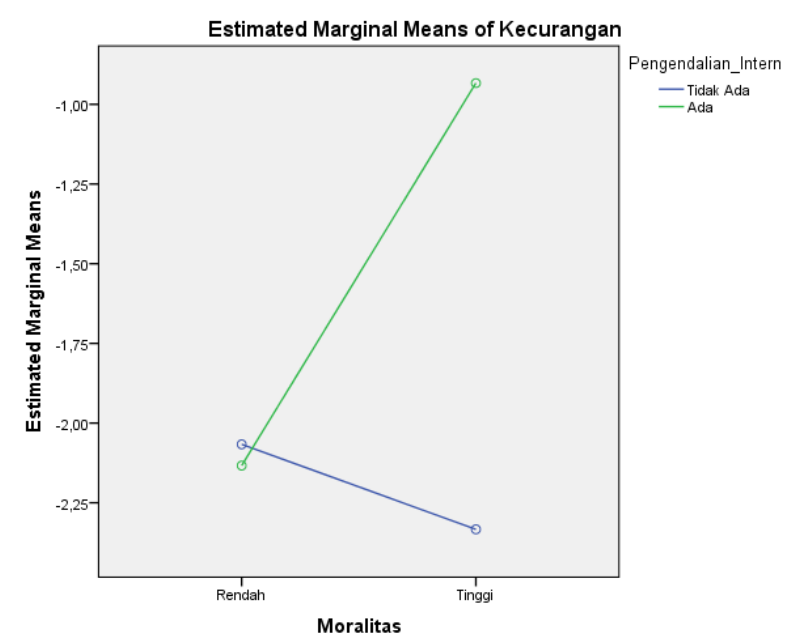

Grafik 1. Profile Plots Interaksi

Tabel 5. Simple Effect

\begin{tabular}{llrl}
\hline PENGENDALIAN_INTERN & $\begin{array}{r}\text { Sum of } \\
\text { Squares }\end{array}$ & Sig. \\
\hline TIDAK & Contrast &, 533 &, 599 \\
ADA & Error & 106,933 & \\
ADA & Contrast & 10,800 &, 021 \\
& Error & 106,933 & \\
\hline
\end{tabular}

Variabel dependen: KECURANGAN

Pada tabel 5 terlihat individu dengan moralitas rendah dan moralitas tinggi tidak secara signifikan berbeda ketika berada pada kondisi tidak terdapat pengendalian internal. Ini dilihat dari hasil nilai signifikansinya sebesar 0,599 $(\mathrm{p}>0,05)$. Sementara itu individu dengan moralitas rendah dan moralitas tinggi berbeda secara signifikan pada kondisi terdapat pengendalian internal. Ini diperlihatkan dari nilai signifikansinya sebesar $0,021(\mathrm{p}<0,05)$. Ketiga hasil pengujian di atas bisa diacusilang ke Tabel 6 .

Efek interaksi (interaction effect) yaitu efek yang diakibatkan oleh adanya interaksi antara satu variabel independen dengan variabel independen lainnya dalam suatu model analisis. Bila dilihat 
pada grafik 1 terlihat bahwa pengaruh dari pengendalian internal tergantung dari moralitas individu. Pada moralitas rendah rata-rata kecurangan yang terjadi disaat tidak ada pergendalian internal dengan ada pengendalian internal tidak jauh berbeda. Selisihnya hanya $0,26 \quad(2,13-2,07)$. Namun, pada moralitas tinggi kecurangan yang terjadi saat tidak ada pengendalian internal dengan ada pengendalian internal selisihnya cukup besar, yaitu $1,2(2,33-0,93)$.

\section{Tabel 6. Tests of Between-Subjects Effects}

\begin{tabular}{lccr}
\hline Sumber & $\begin{array}{c}\text { Type III } \\
\text { Sum of } \\
\text { Squares }\end{array}$ & F & Sig. \\
& $18,000^{\mathrm{a}}$ & 3,142 &, 032 \\
Corrected Model & 209,067 & 109,486 &, 000 \\
Intercept & 3,267 & 1,711 &, 196 \\
Moralitas & 6,667 & 3,491 &, 067 \\
Pengend_Intern & 8,067 & 4,224 &, 045 \\
Moralitas * & 106,933 & & \\
Pengend_Intern & 334,000 & & \\
Error & 124,933 & & \\
Total & & \\
Corrected Total & &
\end{tabular}

a. R Squared $=, 144$ (Adjusted R Squared $=, 098)$

Menurut Leary (2004) pengujian efek simpel dilakukan jika interaksi dua variabel independen signifikan secara statistis. Dalam konteks ini berarti menguji pengaruh moralitas terhadap pengendalian internal apabila terdapat pengendalian internal dan tidak terdapat pengendalian internal. Hasilnya bisa dilihat pada Tabel 5 .

\section{SIMPULAN}

Penelitian ini memberikan sumbangan kepada literatur pengendalian intenal. Pengendalian internal memiliki fungsi, salah satunya, untuk menjaga aset perusahaan dari pencurian. Untuk bisa efektif, maka perlu diketahui faktor-faktor apa yang mempengaruhi kecenderungan kecurangan atau pengurangan kecurangan. Termasuk yang harus diketahui adalah apakah memang pengendalian internal memang memiliki pengaruh terhadap kecenderungan terjadinya kecurangan itu.

Simpulan dari penelitian ini adalah tidak terdapat perbedaan kecenderungan individu dalam melakukan kecurangan antara individu yang memiliki level moral yang tinggi dan individu yang memiliki level moral yang rendah yang mana nilai signifikansi lebih besar dari alpha yang ditetapkan sebesar $5 \%$. Hasil ini berbeda dengan penelitian
Dewi (2014) yang hasil penelitiannya menyatakan terdapat perbedaan signifikan antara individu yang bermoralitas rendah dengan individu yang bermoralitas tinggi terhadap kecurangan akuntansi. Nilai signifikansi dari penelitian Dewi (2014) menghasilkan nilai signifikansi yang lebih kecil dari alpha yang ditetapkan sebesar 5\%.

Simpulan kedua adalah pengendalian internal mempengaruhi kecurangan. Keberadaan pengendalian internal mencegah subjek untuk berperilaku curang. Dalam konteks perusahaan atau organisasi, keberadaan pengendalian internal bisa menjamin bahwa aset perusahaan bisa dijaga dengan lebih baik dibandingkan jika pengendalian internal tidak terpasang. Hasil penelitian ini sejalan dengan penelitian Mazar et al. (2008) dan Thoyyibatun et al. (2009) yang mana keefektifan pengendalian internal berpengaruh negatif terhadap kecurangan akuntansi.

Hasil dari penelitian ini mengindikasikan terdapat interaksi antara level moral individu dengan pengendalian internal. Hal ini dapat terlihat dari hipotesis ketiga, yaitu ada interaksi antara moralitas dengan pengendalian internal terhadap kecurangan. Hasil ini sejalan dengan hasil penelitian Dewi (2014) yang menyatakan terdapat interaksi antara moralitas dengan pengendalian internal terhadap kecurangan akuntansi. Bahwa pengendalian internal tergantung pada moralitas individu. Individu dengan moralitas rendah tidak mempermasalahkan ada tidaknya pengendalian internal dalam melakukan kecurangan. Individu bermoralitas tinggi ketika dihadapkan dengan kondisi terdapat pengendalian internal, kecurangan yang dilakukan cenderung lebih rendah dibanding kondisi tidak terdapat pengendalian internal.

Penelitian ini memiliki beberapa keterbatasan, yaitu; pertama, pelaksanaan pengujian dilakukan di dalam kelas yang cukup ramai dan tidak luas. Subjek tidak dibagi menjadi empat kelompok perlakuan. Subjek dibiarkan berada di dalam satu kelas dengan kemungkinan nilai moralitas yang rendah dan tinggi yang sepekan sebelumnya telah diuji. Interaksi antar-subjek tidak bisa dihindari. Keterbatasan kedua yaitu hasil dari Mach IV test yang menyatakan bahwa sifat Machiavellian dari sampel sangat merata, sehingga ketika mesti dipisahkan antara yang bermoralitas rendah dengan yang bermoralitas tinggi, ada yang bernilai sama namun berada pada kelompok yang berbeda. Pada tes kedua, yaitu add to 10 matrices test, ketika waktu pengerjaan lembar kertas kerja habis dan partisipan disuruh berhenti, masih ada 
partisipan yang mengerjakan lembaran kertas kerja tersebut. Menurut Mc Phail dan Walters (2009), atribut individu seperti kematangan moral, usia, jenis kelamin dan kebangsaan juga mempengaruhi seseorang ketika ia menghadapi dilema etika. Penelitian ini hanya mengukur atribut moral individu. Penelitian selanjutnya harus mengukur atribut pribadi lainnya seperti usia, jenis kelamin, daerah asal atau wilayah.

\section{DAFTAR PUSTAKA}

Abiola I dan T. O Adedokun. 2013. Internal Control System on Fraud Detection: Nigeria Experience. Journal of Accounting and Finance, 13 (5), 545-557.

Arens A. A., J. E, Ronald dan M. S. Beasley. 2004. Auditing Dan Pelayanan Verifikasi Pendekatan Terpadu. Alih Bahasa Tim Dejacarta. Jakarta: PT indeks

Ariely, D. 2013. The Honest Truth About Dishonesty - TAM 2013. https:/www.youtube.com/watch? ${ }_{\mathrm{v}}=\mathrm{G} 2 \mathrm{RKQ}$ $\mathrm{kAoY} 3 \mathrm{k}$

Ayal, S. Dan F. Gino. 2011. Honest rationales for dishonest behavior. In: Mikulincer, M., Shaver, P.R. (Editor). The Social Psychology of Morality: Exploring the causes of Good and Evil. American Psychological Association, Washington, DC.

Badan Pemeriksa Keuangan Republik Indonesia (BPK RI). Peraturan No. 1 Tahun 2007 tentang Standar Pemeriksaan Keuangan.

Badan Pemeriksa Keuangan Republik Indonesia (BPK RI). Ikhtisar Hasil Pemeriksaan Semester 2 Tahun 2015 diakses tgl 27 April 2015 http://www.bpk.go.id/ assets/files/ihps/2015/II/ihps_ii_2015_1460 449853.pdf

Bastian, I. 2015. Akuntansi Sektor Publik: Suatu Pengantar. Jakarta: Erlangga.

Cressey, D. 1973. Other People's Money: a Study in the Social Psychology of Embezzlement. Glencoe, IL: Free Press.

Christie, R. dan F. Geis. 1970. Studies in Machiavellianism. New York. Academic Press.

Coram, P., C. Ferguson R. dan Moroney. 2008. Internal Audit, Alternative Internal Audit Tructures and The Level of Misapropriation of Assets Fraud. Accounting and Finance, 48 (4), 543-559.
COSO. 2013. Internal Control-Integrated Framework: Executive Summary. Durham. North Carolina.

Dewi, G. A. K. R. S. 2014. Pengaruh Moralitas Individu dan Pengendalian Internal pada Kecurangan Akuntansi (Studi Eksperimen pada Pemerintah Daerah Provinsi Bali). Tesis, Universitas Udayana.

Dwiantika, N. 2011. Inilah 9 Kasus Kejahatan Perbankan.

http://bisniskeuangan.kompas.com/read/20 11/05/03/09441743/Inilah.9.Kasus.Kejahata n.Perbankan.

https://henryivpartone.wordpress.com/mac hiavelli-is-your-character-a-high-or-lowmach/

Gino, F., S. Ayal., dan D. Ariely. 2009. Contagion and differentiation in unethical behavior: The effect of one bad apple on the barrel. Psychological Science, 20 (3), 393-398.

Gino, F. dan D. Ariely. 2012. The dark side of creativity: original thinkers can be more dishonest. Journal of personality and social psychology, 102 (3), 445.

Hernandez, J. R. dan T. Groot. 2007. Corporate Fraud: Prepentive Controls Which Lower Corporate Fraud. Amsterdam Research Centre in Accounting.

Houghton, K.A. dan J. J. F. Hronsky. 1993. The sharing of meaning between accounting students and members of the accounting profesion. Accounting and Finance, 33 (2), 131-147.

Ikatan Akuntan Indonesia. 2001. Standar Pemeriksaan Akuntan Publik. SA Seksi 316. Pertimbangan atas Kecurangan dalam Audit Laporan Keuangan.

Ikatan Akuntan Indonesia. 2001. Standar Pemeriksaan Akuntan Publik. SA Seksi 319. Perimbangan Atas Pengendalian Internal Dalam Audit Laporan Keuangan.

Jensen, M. dan W. H. Meckling. 1976. Theory of the Firm: Managerial Behavior, Agency Cost, and ownership Structure, Journal of Financial Economics, 3, 305-360.

Kohlberg, L. 1969. Stage and Sequence: The Cognitive-Development Approach Moral Action to Socialization. In D. A. Goslin (Ed). Handbook of socialization theory and research. Chicago: RandMcNally.

Kohlberg. 1971. Stage of Moral

Development.http://info.psu.edu.sa/psu/ma ths/Stages\%20of\%20Moral\%20Developmen t\%20According\%20to\%20Kohlberg.pdf 
Kramer, D. K. 2014. A Question of Honour: How code of ethical conduct and moral dilemmas impact behavior. Hamburg: Anchor Academic Publishing

Liyanarachi, G. dan C. J. Newdick. 2009. The Impact of Moral Reasoning and Retaliation on Whistle-Blowing: New-Zealand Evidence. Journal of Business Ethics, 89 (1), 37-57

Leary, M. R. 2012. Introduction to Behavioral Research Method. Sixth Edition. New Jersey: Pearson Education Inc.

Mazar, N. dan D. Ariely. 2006. Dishonesty in everyday life and its policy implication. Journal of Public Policy and Marketing, 25 (1), 117-126.

Mazar, N, O. Amir dan D. Ariely. 2008. The Dishonesty of Honest People: A Theory of Self-Concept Maintenance. Journal of Marketing Research, 45 (6), 633-644.

Moroney, J. J. dan R. E. McDevitt. 2008. The Effects of Moral Reasoning on Financial Reporting Decisions in a Post SarbanesOxley Environment. Behavioral Research of Accounting. Behavioral Research in Accounting, 20 (2) 89-110

Pope, R. K. 2005. Measuring the Ethical Propensities of Accounting Students: Mach IV versus DIT. Journal of Academic Ethics 3 (2), 89-111.

Puspasari, N. 2012. Pengaruh Moralitas Individu dan Pengendalian Internal terhadap Kecenderungan Kecurangan Akuntansi: Studi Eksperimen pada Konteks Pemerintahan Daerah. Tesis, Universitas Gajah Mada.

Ramamoorti, S. 2008. The Psychology and Sociology of Fraud: Integrating the Behavioral Sciences Component Into Fraud and Forensic Acounting Curricula. Issues in Accounting Education, 23 (4), 521-533.

Remus, W. 1986. Graduate students as surrogates for managers in experiments on business decision making. Journal of Business Research, 14, 19-25.

Rest, J. R. (2000). A Neo-Kohlbergian Approach To Morality Research. Journal of Moral Education, 29 (4), 381-395.

Sawyer, L. B., M. A. Dittenhofer dan J. H. Scheiner. 2005, Internal Auditing, Diterjemahkan oleh : Desi Adhariani, Jilid 1, Edisi 5, Jakarta: Salemba Empat.

Sawyer, L. B., M. A. Dittenhofer dan J. H. Scheiner. 2006, Internal Auditing, Diterjemahkan oleh: Ali Akbar, Jilid 3, Edisi 5, Jakarta: Salemba Empat.
Sekaran, U. 2006. Research Methods for Business. Edisi 4. Buku 2. Jakarta: Salemba Empat.

Singleton, T. W. dan A. J. Singleton. 2010. Fraud Auditing danForensic Accounting, $4^{\text {th }}$ edition, New Jersey: John Wiley dan Son Inc.

Thoyyibatun S., M. Sudarna dan E. G. Sukoharsono. 2009. Analysing The Influence of Internal Control Compliance and Compensation System Against Unethical Behavior and Accounting Fraud Tendency. Paper Dipresentasikan pada Simposium Nasional Akuntansi IX, Padang. 